L'établissement d'une carte linguistique du Tchad est la première tâche confiée à la section linguistique. Cette carte figurera dans l'Atlas général tchadien dont la réalisation a été entreprise par la section de géographie de l'I.N.T.S.H. dirigée par M. le Doyen Jean Cabot.

\title{
The Nigerian Geographical Association: 14th Annual Conference, 1969
}

THE Conference, which took as its general theme 'Geography for development', was planned and arranged by the Department of Geography at Ahmadu Bello University. The Presidential Address, on the subject 'The role of geographers in national reconstruction', was given by Professor R. A. A kinola, and the following open lectures were delivered: 'Industrialization in West Africa: the need for sub-regional groupings within a regionally integrated economic community' (Professor K. M. Barbour); 'Migration policy and regional development in Nigeria' (Professor A. L. Mabogunje); 'Upper air and surface weather' (Dr. P. N. Hore); 'Travel behaviour patterns and economic development in Nigeria ' (Dr. G. J. Afolabi Ojo). The Conference had a dual emphasis on the educational role of the subject in Nigeria and on its practical applications in such fields as regional planning and land resource assessment.

\section{African Studies at the National Chengchi University, Taiwan}

THE Graduate Institute of the National Chengchi University (Mushan, Taipei, Taiwan) is developing its Program of African Studies. In addition to the course on Contemporary Africa given since 1964 by the Director Dr. Tu Kwang-hsun, Dr. F. M. Bourret (of the Sacred Heart, Taipei) is giving a course on Political Development in West Africa and Mr. Chin, who has returned from graduate studies and field-work in London and Ghana, is teaching on the Modern History of Africa.

\section{Rhodes University, Grahamstown: Institute of Social and Economic Research}

RESEARCH projects being undertaken and prepared for publication by members of the Department of African Studies include the following: The decision-making process in a rural community: Lesotho (J. A. G. Perry); A study of a Chopi community in Inharrine, Moçambique (D. G. Webster); A community settlement scheme in João Bello, Moçambique (Miss K. Mack); Social and economic change in a Swazi rutal community (A. N. Ross). Professor Philip Mayer of the University of Durham, formerly head of the Department of African Studies, has been awarded the University Fellowship for 1970 and is continuing his researches among the Cape Nguni people.

\section{Project for a Centre of New Religious Movements at the University of Lancaster (England)}

A PRELIMINARY announcement is made of the plan recently adopted by the University of Lancaster (England) for the establishment of a Centre for New Religious Movements during the next university quinquennium, 1972-7. This will encourage interdisciplinary and comparative study of the modern religious movements familiar to Africanists, and also of their equivalents in the Americas, Australia, Oceania, and parts of Asia. The Centre will be connected with the Department of Religious Studies under Professor Ninian Smart but also with other relevant departments, and will be under the direction of Dr. H. W. Turner. It is aimed to provide world documentation in this field, to offer an M.A. by course work, research facilities for higher degrees, and if funds permit to become the first depository 
in the United Kingdom for the Human Relations Area Files from New Haven, Connecticut. In the intervening period inquiries should be addressed (from September 1970) to Professor H. W. Turner, Candler School of Theology, Emory University, Atlanta, Ga. 30322, U.S.A., or to Professor R. N. Smart at Lancaster.

\section{The Herskovits Award for 1969}

Dr. Paul and Dr. Laura Bohannan were awarded the 1969 Herskovits Award of the African Studies Association (U.S.A.) for their book, Tiv Economy. They are the authors of the International African Institute's Ethnographic Survey section on The Tiv of Central Nigeria, which was reprinted in 1969 with a supplementary bibliography. Dr. Paul Bohannan's study of Justice and Judgment among the Tiv (1957), also published by the Institute, was reprinted in 1968 with a new Preface.

\section{The Co-operative African Microform Project (CAMP)}

CAMP, which is administered by the Center for Research Libraries in Chicago and sponsored by the Archives-Libraries Committee of the African Studies Association, has received a second grant from the U.S. Department of Health, Education, and Welfare, enabling it to buy or film an extensive range of new titles so that by the end of the present fiscal year there should be almost 1,000 titles available. Recent additions include the correspondence and memoranda files of the South African Institute of Race Relations, various newspapers, several hundred out of print books on former French West Africa, a number of Italian books on the Horn, a group of British, American, and continental European dissertations on African topics, a set of Tanganyika District Books, and such major journals as Nigeria Magazine, Gold Coast Review, and Black Orphews.

A number of member libraries have deposited surplus films and negatives in exchange for positives in CAMP; other libraries and individuals are invited to do the same to increase the pool of Africanist materials.

A new prospectus describing the work of CAMP may be obtained from Robert Gordon Collier, Assistant Director of the Center for Research Libraries, 5721 Cottage Grove, Chicago, Ill., 60637. Copies of the Center's Handbook and of the various CAMP accessions lists are also available on request by prospective members.

\section{'Transafrican Journal of History'}

THE first issue of the Transafrican Journal of History, edited by J. A. Kieran (University College, Nairobi) and A. D. Roberts (University of Zambia) will appear in September r970. It will be issued twice a year and will mainly be concerned with the history of eastern and central Africa since about 1800 , though the editors will welcome articles of general interest to African historians on earlier history, and on the history of other parts of the world. The annual subscription (Shs. 20 in East Africa and f2. I 2 s. or $\$ 6$ elsewhere) should be sent to the publishers, East African Publishing House, P.O. Box 30571, Nairobi, Kenya. Articles (which should not normally be more than 7,000 words in length) and books for review should be sent to the editors c/o Dept of History, University College, P.O. Box 30197 , Nairobi, Kenya.

\section{'Studies in African Linguistics'}

The Department of Linguistics and the African Studies Center, University of California, Los Angeles, announces the publication of this new journal of theoretical linguistics. The contents of the first issue (vol. I, no. r) are: 